4.0 International License

\title{
ANALISIS KESIAPAN GURU IPA DALAM IMPLEMENTASI KURIKULUM 2013 DI SMP NEGERI SE- KECAMATAN STABAT
}

\author{
Layil Safitri \\ Universitas Nahdlatul Ulama Sumatera Utara \\ Mrs.layil1991@gmail.com
}

\begin{abstract}
The study of Science Teacher Readiness Analysis in 2013 Curriculum Implementation in this Public Middle School aims to find out: the readiness of Junior High School science teachers in preparing learning by implementing the 2013 curriculum and the readiness of junior high school science teachers in preparing learning tools by implementing the 2013 curriculum. The subjects in this study were 2 teachers Stabat 1 state junior high school, 4 Stabat state 2 junior high school teachers, and 5 Stabat state 5 junior high school teachers. This type of research is quantitative descriptive analysis research. The results showed that: State Junior High School Teachers in Stabat Subdistrict were declared ready in preparing the 2013 curriculum learning, this can be seen from the average percentage of $79 \%$ with the ready category; State Junior High School Teachers in Stabat Subdistrict are in the ready category in preparing the 2013 curriculum learning tools, this can be seen from the following data: Average percentage of readiness of Stabat 1 Public Middle School teachers is $79 \%$ with ready category. The average percentage of readiness of Stabat 2 state junior high school teachers is $70 \%$ in the ready category.
\end{abstract}

Keywords: Readiness; Science Teachers; 2013 Curriculum.

\begin{abstract}
Abstrak. Penelitian Analisis Kesiapan Guru IPA dalam Implementasi Kurikulum 2013 di SMP Negeri ini bertujuan untuk mengetahui: kesiapan guru IPA SMP dalam menyiapkan pembelajaran dengan mengimplementasikan kurikulum 2013 dan kesiapan guru IPA SMP dalam menyiapkan perangkat pembelajaran dengan mengimplementasikan kurikulum 2013. Subyek dalam penelitian ini adalah 2 orang guru SMP negeri 1 Stabat, 4 orang guru SMP negeri 2 Stabat, dan 5 orang guru SMP negeri 5 Stabat. Jenis penelitian ini adalah penelitian analisis deskriptif kuantitatif. Hasil penelitian menunjukkan bahwa: Guru SMP Negeri se-Kecamatan Stabat dinyatakan siap dalam menyiapkan pembelajaran kurikulum 2013, hal ini dapat dilihat dari rata-rata persentase sebesar $79 \%$ dengan kategori siap; Guru SMP Negeri se-Kecamatan Stabat memiliki kategori siap dalam menyiapkan perangkat pembelajaran kurikulum 2013, hal ini dapat dilihat dari data sebagai berikut: Rata-rata persentase kesiapan guru SMP negeri 1 Stabat sebesar $79 \%$ dengan kategori siap. Rata-rata persentase kesiapan guru SMP negeri 2 Stabat sebesar $70 \%$ dengan kategori siap. Rata-rata persentase kesiapan guru SMP negeri 5 Stabat sebesar $78 \%$ dengan kategori siap.
\end{abstract}

Kata Kunci : Kesiapan; Guru IPA; Kurikulum 2013. 


\section{PENDAHULUAN}

Kurikulum adalah suatu hal yang esensial dalam suatu penyelenggaraan pendidikan. Secara sederhana, kurikulum dapat dimengerti sebagai suatu kumpulan atau daftar pelajaran yang akan diajarkan kepada peserta didik komplit dengan cara pemberian nilai pencapaian belajar dikurun waktu tertentu. Kurikulum harus mampu mengakomodasi kebutuhan peserta didik yang berbeda secara individual, baik ditinjau dari segi waktu maupun kemampuan belajar.Oleh karena itu, merumuskan suatu kurikulum sudah barang tentu bukan perkara gampang. Banyak faktor yang menentukan dalam proses lahirnya sebuah kurikulum.

Merancang kurikulum biasanya dibentuk suatu tim kerja khusus yang dapat berupa lembaga resmi, misalnya pusat Departemen Nasional Pusat Kurikulum sampai saat ini sebagai satu-satunya lembaga resmi bermandat menelurkan kurikulum bagi sekolah penyelenggara pendidikan nasional Indonesia. Sebagaimana penelitian yang dilakukan Qomariyah dalam penelitannya "Kesiapan Guru Dalam Menghadapi Implemetasi Kurikulum 2013," beliau menyatakan bahwa “ tercatat sudah ada sebelas kurikulum, antara lain, kurikulum tahun 1947, kurikulum tahun 1964 (rencana pendidikan sekolah dasar), kurikulum tahun 1968 (kurikulum sekolah dasar), kurikulum tahun 1973 (kurikulum proyek perintis sekolah pembangunan/ PPSP), kurikulum tahun 1975 (kurikulum sekolah dasar), kurikulum tahun 1984 (kurikulum 1984), kurikulum tahun 1994 (kurikulum 1994), kurikulum tahun 1997 (revisi kurikulum 1994), kurikulum tahun 2004 (rintisan kurikulum berbasis kompetensi/ KBK), kurikulum tahun 2006 (kurikulum tingkat satuan pendidikan/ KTSP), dan yang terakhir kurikulum 2013. Masing-masing kurikulum memiliki warna dan ciri khas tersendiri.Warna dan ciri khas kurikulum menunjukkan kurikulum berusaha menghadirkan sosok peserta didik yang paling pas dengan jamannya.

Berdasarkan pernyataan di atas, terdapat beberapa kurikulum, diantaranya rencana pendidikan sekolah dasar kemudian mengalami perubahan menjadi kurikulum sekolah dasar pada tahun 1968 dan dilanjutkan kepada kurikulum proyek perintis sekolah pembangunan/PPSP yang dilaksanakan pada tahun 1973 kemudian mengalami perubahan kembali ke kurikulum awal yakni kurikulum sekolah dasar pada tahun 1975 kemudian pada tahun 2004 dirintislah kurikulum berbasis kompetensi/ KBK dan pada tahun 2006 diubah kembali ke kurikulum tingkat satuan pendidikan/ KTSP dan berakhir pada tahun 2013 dengan hadirnya kurikulum 2013. Perbedaan antar tiap kurikulum terdapat pada warna dan ciri khasnya masing-masing dan masing-masing kurikulum memiliki kekurangan dan kelebihan.Adapun warna dan ciri khas tiap kurikulum tersebut disesuaikan dengan kebutuhan siswa tiap zamannya.

Perubahan kurikulum dari waktu ke waktu bukan tanpa alasan dan landasan yang jelas, sebab perubahan ini disemangati oleh keinginan untuk terus memperbaiki, mengembangkan, dan meningkatkan kualitas sistem pendidikan nasional.Lembaga sekolah sebagai ujung tombak dalam implementasi kurikulum dituntut untuk memahami dan mengaplikasikannya secara optimal dan penuh kesungguhan, sebab mutu penyelenggaraan pendidikan salah satunya dilihat dari hal tersebut. Namun di lapangan, perubahan kurikulum sering kali menimbulkan persoalan baru, sehingga pada tahap implementasinya memiliki kendala teknis, sehingga sekolah sebagai penyelenggara proses pendidikan formal sedikit banyaknya pada tahap awal ini membutuhkan energi yang besar hanya untuk mengetahui dan memahami isi dan tujuan kurikulum baru. Dalam teknik pelaksanaannya pun sedikit terkendala disebabkan perlu adaptasi terhadap perubahan atas kurikulum terdahulu yang sudah biasa diterapkan.

Struktur kurikulum juga gambaran mengenai penerapan prinsip kurikulum mengenai posisi seorang siswa dalam menyelesaikan pembelajaran di suatu satuan atau jenjang pendidikan.Dalam struktur kurikulum menggambarkan ide kurikulum mengenai posisi belajar seorang siswa yaitu apakah mereka harus menyelesaikan seluruh pelajaran yang tercantum dalam struktur ataukah kurikulum memberi kesempatan kepada siswa untuk menetukan berbagai pilihan.

Dalam studi tentang ilmu mengajar dan kurikulum, pembahasan mengenai permasalahan yang dialami guru senantiasa mendapat tempat tersendiri dan mendapat perhatian yang sangat serius. Hal ini 
dikarenakan guru mengemban peran yang sangat penting dalam keberhasilan proses pendidikan. Betapa bagus dan indahnya kurikulum, keberhasilan kurikulum tersebut pada akhirnya bergantung pada masing-masing guru. Qomariyah juga memberikan pendapat tentang kurang siapnya guru pengajar dalam menghadapi implementasi kurikulum 2013, hal ini dapat dilihat dari program kepala madrasah MTs Al Fitroh dalam rangka menghadapi implementasi kurikulum 2013, sekolah dan guru pengajar bisadinyatakan kurang siap dalam menghadapi implementasi kurikulum ini. Hal ini disebabkan oleh beberapa guru belum mengerti dan belum paham akan kurikulum 2013, guru jarang mengikuti kegiatan-kegiatan penataran dan upgrading, dan guru jarang mengikuti pelatihan mengenai pengembangan pembelajaran, model dan motivasi lain.

Kurikulum 2013 adalah salah satu kurikulum yang menerapkan pembelajaran dengan pendekatan ilmiah (scientific approach) maka guru harus memahami dan mengerti tentang pendekatan ilmiah tersebut.Dari permasalahan tersebut dapat dilihat bahwa kemampuan pedagogik dapat memengaruhi keberhasilan pembelajaran.Keberhasilan tersebut dapat terlihat dari persiapan (RPP, silabus, sarana prasarana) dan proses (mengamati, menanya, menalar, mencoba, membentuk jejaring) pembelajaran yang terlaksana. Sama halnya seperti yang disampaikan oleh Retno dan Heriyatmi dengan penelitian yang berjudul “ Kemampuan Guru IPA dalam Penerapan Kurikulum 2013 di SMP Boyolali Tahun 2013/2014," beliau mengatakan "kurikulum 2013 memiliki komponen-komponen pengembangan kurikulum yang terdiri dari komponen tujuan, komponen isi, komponen metode, dan komponen evaluasi."

Berdasarkan pernyataan di atas, peneliti menarik kesimpulan bahwa kurikulum 2013 sudah mengalami perkembangan dari segi komponen tujuan, isi, metode, serta evaluasi. Adapun komponen tujuan terdiri dari KI (Kompetensi Inti) dan KD (Kompetensi Dasar) ; indikator, tujuan pembelajaran. Pada komponen isi meliputi materi pembelajaran dan langkah- langkah kegiatan pembelajaran. Serta pada komponen evaluasi yang berupa penilaian baik dalam bentuk tes (pilihan berganda dan essay) dan non tes (PBK/ penilaian berbasis kelas). Pada tahap evaluasi harus mencakup tiga ranah kompetensi siswa yakni sikap spiritual, sikap sosial, dan pengetahuan.

Adanya penerapan kurikulum 2013, guru harus mulai terbiasa dengan adanya peraturan yang telah ditetapkan tersebut, sehingga strategi yang digunakan seperti mengamati, menanya, menalar, mencoba, membentuk jejaring akan terlaksana dengan baik dan maksimal. Kemampuan seorang guru dapat dilihat pada saat pelaksanaan pembelajaran berlangsung. Untuk menumbuhkan rasa semangat dan ingin tau siswa, guru hendaknya memakai strategi yang menarik dalam pembelajaran.Strategi pembelajaran yang digunakan oleh guru yang menyenangkan juga harus sesuai dengan kemampuan guru dan sesuai dengan kurikulum yang telah diterapkan.

Dengan diberlakukannya kurikulum 2013, maka pemerintah mempunyai harapan yang besar bagi dunia pendidikan terutama bagi guru yang diharapkan mampu mengimplementasikan metode pembelajaran yang inovatif (student-centered) karena hal ini disebabkan pembelajaran konvensional (teacher-centered) dianggap tidak lagi mampu memenuhi harapan- harapan di atas. Agar siswa mampu mengembangkan sikap dan pengalaman sesuai dengan perbedaan potensinya, maka peran guru tidak lagi sebagai pentransfer ilmu, melainkan sebagai fasilitator atau membantu siswa agar siswa mampu menguasai berbagai kompetensi yang diharapkan.

Berdasarkan uraian tersebut di atas menjadi landasan bagi peneliti untuk mengadakan penelitian dengan judul "Analisis Kesiapan Guru IPA Dalam Implementasi Kurikulum 2013 di 5 SMP se-Kecamatan Stabat."

Berdasarkan batasan penelitian di atas, maka peneliti merumuskan masalah hanya pada: (1) Bagaimana kesiapan guru IPA SMP dalam menyiapkan pembelajaran dengan mengimplementasikan kurikulum 2013? (2) Bagaimana kesiapan guru IPA SMP dalam menyiapkan perangkat pembelajaran dengan mengimplementasikan kurikulum 2013?

Berdasarkan rumusan masalah di atas, maka tujuan penelitiannya adalah sebagai berikut: (1) Untuk mengetahui kesiapan guru IPA dalam menyiapkan pembelajaran dengan mengimplementasikan kurikulum 2013 dan (2) Untuk mengetahui perangkat yang 
dipersiapkan guru IPA SMP dalam mengimplementasikan kurikulum 2013.

Pada penelitian ini terdapat dua manfaat penelitian yakni manfaat teoretis dan manfaat praktis, berikut akan dipaparkan kedua manfaat tersebut.

1. Manfaat Teoretis

a. Penelitian ini diharapkan dapat memberikan wawasan dan pengetahuan baru tentang implementasi kurikulum 2013 pada guru dan tenaga pengajar.

b. Penelitian ini menjadi salah satu tolak ukur dalam menilai kesiapan guru dalam melaksanakan kurikulum 2013.

c. Penelitian ini menjadi bahan acuan bagi peneliti selanjutnya dalam melakukan penelitian yang sama.

2. Manfaat Praktis

a. Penelitian ini memberikan pengalaman bagi peneliti tentang implementasi kurikulum 2013 di sekolah tempat melakukan penelitian.

b. Penelitian ini memberikan pandangan baru pada guru dan tenaga pengajar mengenai implementasi kurikulum 2013 di tempat penelitian dilakukan.

\section{METODE PENELITIAN}

Penelitian ini merupakan penelitian deskriptif kuantitatif non hipotesis dengan menggunakan pendekatan survey, yaitu penelitian yang bersifat mengumpulkan data sebanyak-banyaknya mengenai kesiapan guru IPA dalam mengimplementasikan kurikulum 2013. Data yang diperoleh dalam penelitian ini berupa data kualitatif dan data kuantitatif. Selanjutnya dalam penelitian kualitatif, jumlah sampel tidak perlu terlalu banyak karena tujuannya adalah untuk menganalisis lebih dalam mengenai sebuah fenomena atau kejadian.

Jenis data yang diperoleh dari penelitian ini adalah data kuantitatif. Pengumpulan data dilakukan dengan metode survey menggunakan angket, lembar observasi dan studi dokumentasi.

Teknik pengumpulan data menggunakan angket dalam penelitian ini ditujukan kepada guru IPA SMP (sampel penelitian) guna mendapatkan informasi tentang kesiapan guru mengenai implementasi kurikulum 2013, meliputi (1) pengembangan perangkat pembelajaran;(2) perencanaan pembelajaran; (3) pelaksanaan pembelajaran; dan (4) evaluasi hasil belajar. Untuk pernyataan angket berbentuk positif, pemberian skor dengan menggunakan kriteria sebagai berikut:

SL (selalu) diberi skor 4

SR (sering) diberi skor 3

KD (kadang-kadang) diberi skor 2

TP (tidak pernah) diberi skor 1

Angket yang digunakan adalah angket tertutup dengan bentuk centang. Dalam angket ini responden memberikan jawaban mengenai dirinya sendiri.

Observasi ini berupa lembar hasil observasi yang menilai tentang kesiapan guru IPA dalam implementasi kurikulum 2013 pada pembelajaran IPA yang disusun oleh guru kemudian ditabulasi yang berisikan tentang:

1. Komponen-komponen kurikulum 2013 yang meliputi: Prota dan prosem; rincian minggu efektif (RME); perencanaan pembelajaran; pelaksanaan pembelajaran; dan evaluasi pembelajaran.

2. Indikator pada setiap komponen- komponen diatas digambarkan melalui beberapa deskriptor yang selanjutnya diberi penilaian berdasarkan pengamatan secara praktik dan prosedur.

3. Kategori yang menerangkan tentang skor yang diperoleh dari setiap indikator dari masing-masing kegiatannya. Dalam hal ini peneliti menggunakan skala likert dengan bentuk skala positif. Adapun pemberian skor untuk tiap jawaban adalah:

$$
\begin{aligned}
& \text { Skor } 1=\text { sangat tidak siap } \\
& \text { Skor } 2=\text { tidak siap } \\
& \text { Skor } 3=\text { siap } \\
& \text { Skor } 4=\text { sangat siap }
\end{aligned}
$$

(Sugiyono, 2012: 93)

Dokumentasi digunakan untuk memperoleh data secara visual tentang SMP se-kecamatan Stabat dan data tentang guru IPA SMP se-kecamatan Stabat sebagai sampel penelitian.

\section{Teknik Analisis Data}

Data yang akan dikumpulkan adalah data tentang kesiapan guru IPA dalam implementasi kurikulum 2013 melalui angket dan lembar observasi. Kemudian data dianalisis dengan menggunakan statistik deskriptif (skor rata-rata dan persentase), yaitu menghitung persentase indikator kesiapan guru IPA dalam implementasi kurikulum 2013, menggunakan rumus sebagai berikut. 
Persentase skor kesesuaian= $\frac{\text { jumlah skor yang diperoleh }}{\text { jumlah total skor ideal }} \times 100 \%$

Menggunakan rumus di atas akan menghasilkan perhitungan angka dalam bentuk persen. Klasifikasi skor lalu diubah menjadi klasifikasi dalam bentuk persentase. Nana Sudjana (2005) selanjutnya ditafsirkan dengan kalimat bersifat kualitatif yang tercantum pada tabel berikut ini:

Tabel 1. Persentase Kriteria Keseuaian Indikator Karakter

\begin{tabular}{cccc}
\hline No & $\begin{array}{c}\text { Tingkat } \\
\text { Kelayakan }\end{array}$ & Nilai & Kriteria \\
\hline 1 & $80 \% \leq \mathrm{X} \geq 100 \%$ & A & Sangat Siap \\
2 & $60 \% \leq \mathrm{X} \geq 80 \%$ & B & Siap \\
3 & $40 \% \leq \mathrm{X} \geq 60 \%$ & C & Cukup Siap \\
4 & $20 \% \leq \mathrm{X} \geq 40 \%$ & D & $\begin{array}{c}\text { Kurang } \\
\text { Siap }\end{array}$ \\
5 & $0 \% \leq \mathrm{X} \geq 20 \%$ & E & \begin{tabular}{c} 
Tidak Siap \\
\hline
\end{tabular} \\
\hline
\end{tabular}

\section{HASIL PENELITIAN DAN} PEMBAHASAN

1. Persentase Kesiapan Guru IPA SMP Negeri 1 Stabat

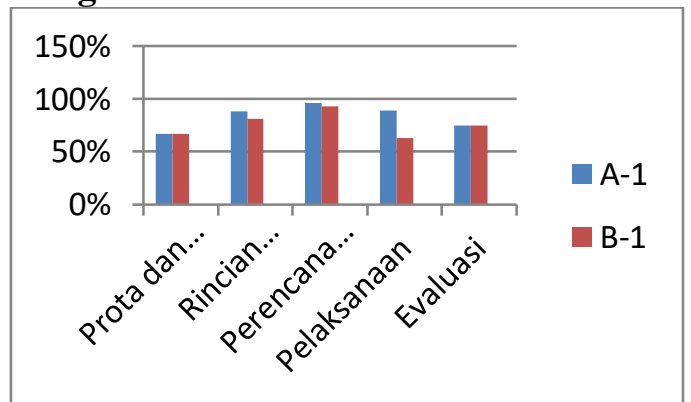

\section{Gambar 1. Persentase Kesiapan Guru IPA SMP Negeri 1 Stabat}

Hasil penilaian menunjukkan bahwa persentase prota dan prosem A-1 sebesar 67\% dengan kategori siap dan B-1 sebesar $67 \%$ dengan kategori siap; persentase rincian minggu efektif (RME) A-1 sebesar 88\% dengan kategori sangat siap dan B-1 sebesar $81 \%$ dengan kategori sangat siap ; persentase perencanaan A-1 sebesar 96\% dengan kategori sangat siap dan B-1 sebesar 93\% dengan kategori sangat siap ; persentase pelaksanaan A-1 sebesar $89 \%$ dengan kategori sangat siap dan B-1 sebesar $63 \%$ dengan kategori siap; dan persentase evaluasi A-1 sebesar $75 \%$ dengan kategori siap dan B-1 sebesar 75\% dengan kategori siap. Rata-rata persentase kesiapan guru PNS IPA SMP Negeri 1 Stabat sebesar 79 dengan kategori siap.

\section{Persentase Kesiapan Guru IPA SMP} Negeri 2 Stabat

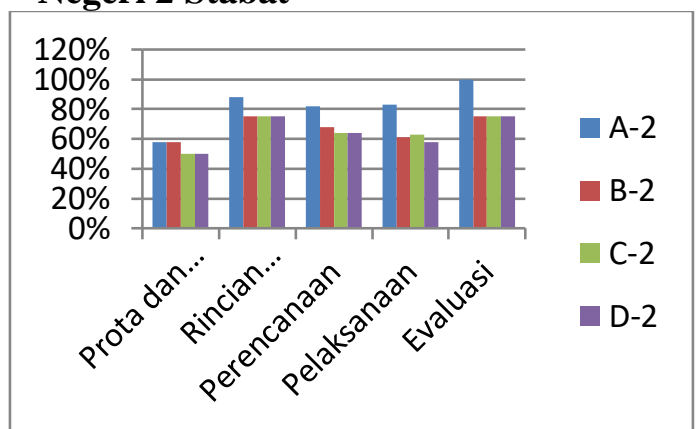

\section{Gambar 2. Persentase Kesiapan Guru IPA SMP Negeri 2 Stabat}

Hasil penilaian menunjukkan bahwa persentase prota dan prosem A-2 sebesar 58\% dengan kategori cukup siap, B-2 sebesar 58\% dengan kategori cukup siap, C-2 sebesar 50\% dengan kategori cukup siap, dan D-2 sebesar $50 \%$ dengan kategori cukup siap; persentase rincian minggu efektif (RME) A-2 sebesar $88 \%$ dengan kategori sangat siap, B-2 sebesar $75 \%$ dengan kategori siap, C-2 sebesar $75 \%$ dengan kategori siap, dan D-2 sebesar $75 \%$ dengan kategori siap ; persentase perencanaan A-2 sebesar $82 \%$ dengan kategori sangat siap, B-2 sebesar $68 \%$ dengan kategori siap, C-2 sebesar $64 \%$ dengan kategori siap dan D-2 sebesar $64 \%$ dengan kategori siap ; persentase pelaksanaan A-2 sebesar $83 \%$ dengan kategori sangat siap, B-2 sebesar $61 \%$ dengan kategori siap, C-2 sebesar $63 \%$ dengan kategori siap, dan D-2 sebesar 58\% dengan kategori cukup siap; dan persentase evaluasi A-2 sebesar $100 \%$ dengan kategori sangat siap, B-2 sebesar $75 \%$ dengan kategori siap, C-2 sebesar 75\% dengan kategori siap, dan D-2 sebesar $75 \%$ dengan kategori siap. Rata-rata persentase kesiapan guru PNS IPA SMP negeri 2 Stabat sebesar $70 \%$ dengan kategori siap.

\section{Persentase Kesiapan Guru IPA SMP Negeri 5 Stabat}




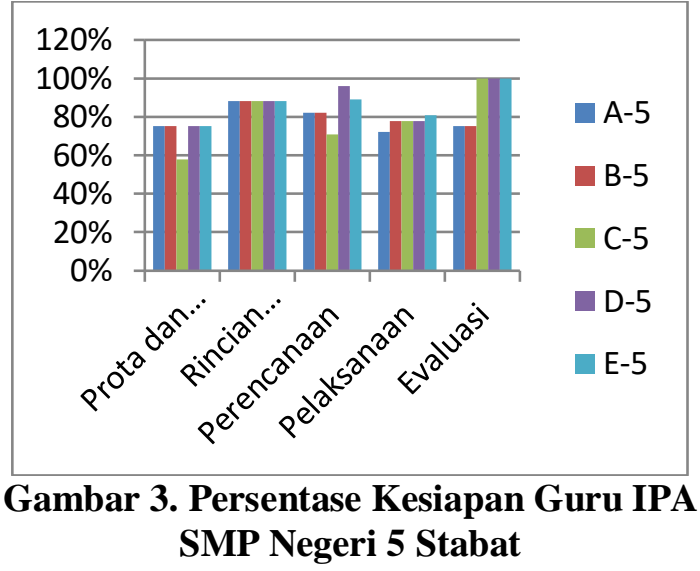

Hasil penilaian menunjukkan bahwa persentase prota dan prosem A-5 sebesar 75\% dengan kategori siap, B-5 sebesar 75\% dengan kategori siap, C-5 sebesar 58\% dengan kategori cukup siap, D-5 sebesar 75\% dengan kategori siap dan E-5 sebesar $75 \%$ dengan kategori siap; persentase rincian minggu efektif (RME) A-5 sebesar 88\% dengan kategori sangat siap, B-5 sebesar $88 \%$ dengan kategori sangat siap, C-5 sebesar $88 \%$ dengan kategori sangat siap, D-5 sebesar 88\% dan E-5 sebesar $88 \%$ dengan kategori sangat siap ; persentase perencanaan A-5 sebesar $82 \%$ dengan kategori sangat siap, B-5 sebesar $82 \%$ dengan kategori sangat siap, C-5 sebesar 71\% dengan kategori siap D-5 sebesar 96\% dan E-5 sebesar $89 \%$ dengan kategori sangat siap ; persentase pelaksanaan A-5 sebesar $72 \%$ dengan kategori siap, B-5 sebesar 78\% dengan kategori siap, C-5 sebesar $78 \%$ dengan kategori siap, D-5 sebesar $78 \%$ dengan kategori siap dan E-5 sebesar $81 \%$ dengan kategori sangat siap; dan persentase evaluasi A-5 sebesar $75 \%$ dengan kategori siap, B-5 sebesar $75 \%$ dengan kategori siap, C-5 sebesar $75 \%$ dengan kategori siap, D-5 sebesar $75 \%$ dengan kategori siap dan E-5 sebesar $75 \%$ dengan kategori siap. Rata-rata persentase kesiapan guru PNS IPA SMP se- kecamatan Stabat sebesar $76 \%$ dengan kategori siap.

Pada proses analisis kesiapan guru IPA SMP se-Kecamatan Stabat, yang menjadi dasar penelitian pada kurikulum 2013 yang memiliki beberapa aspek diantaranya tujuan, isi, metode, serta evaluasi. Setiap aspeknya memiliki indikator yang perlu diteliti. Mulai dari tujuan, yang meliputi prota dan prosem juga rincian minggu efektif (RME), dilanjutkan dengan isi yang meliputi perencanaan dan pelaksanaan pembelajaran, segi metode yang meliputi strategi, pendekatan, langkah pembelajaran hingga media pembelajaran, dan diakhiri dengan evaluasi yang meliputi penilaian berbasis kelas yang lebih mengedepankan proses.

Persentase hasil pengisian angket guru IPA yang mengimplementasikan kurikulum 2013 di SMP Negeri 1 Stabat (-1), SMP Negeri 2 Stabat (-2) dan SMP Negeri 5 Stabat (-5) diperoleh data sebagai berikut: (a) A-1 memperoleh skor 74 dengan persentase 93 berkategori sangat siap dan B-1 memperoleh skor 62 dengan persentase 78 berkategori siap; (b) A-2 memperoleh skor 57 dengan persentase 71 berkategori siap, B-2 memperoleh skor 56 dengan persentase 70 berkategori siap, C-2 memperoleh skor 62 dengan persentase 78 berkategori siap, D-2 memperoleh skor 56 dengan persentase 70 berkategori siap, ; dan (c) A-5 memperoleh skor 56 dengan persentase 70 berkategori siap, B-5 memperoleh skor 72 dengan persentase 90 berkategori sangat siap, C-5 memperoleh skor 68 dengan persentase 85 berkategori sangat siap, D-5 memperoleh skor 72 dengan persentase 90 berkategori sangat siap, dan E-5 memperoleh skor 60 dengan persentase 75 berkategori siap. Rata-rata persentase kesiapan guru PNS IPA SMP se- kecamatan Stabat sebesar $79 \%$ dengan kategori siap.

Hasil observasi kesiapan guru IPA SMP negeri 1 Stabat menunjukkan bahwa persentase prota dan prosem A-1 sebesar $67 \%$ dengan kategori siap dan B-1 sebesar $67 \%$ dengan kategori siap; persentase rincian minggu efektif (RME) A-1 sebesar 88\% dengan kategori sangat siap dan B-1 sebesar $81 \%$ dengan kategori sangat siap ; persentase perencanaan A-1 sebesar 96\% dengan kategori sangat siap dan B-1 sebesar 93\% dengan kategori sangat siap ; persentase pelaksanaan A-1 sebesar $89 \%$ dengan kategori sangat siap dan B-1 sebesar $63 \%$ dengan kategori siap; dan persentase evaluasi A-1 sebesar $75 \%$ dengan kategori siap dan B-1 sebesar 75\% dengan kategori siap. Rata-rata persentase kesiapan guru IPA SMP negeri 1 Stabat sebesar $79 \%$ dengan kategori siap.

Hasil observasi kesiapan guru IPA SMP negeri 2 Stabat menunjukkan bahwa persentase prota dan prosem A-2 sebesar $58 \%$ dengan kategori cukup siap, B-2 sebesar 58\% dengan kategori cukup siap, C-2 sebesar 50\% dengan kategori cukup siap, dan D-2 sebesar $50 \%$ dengan kategori cukup siap; persentase 
rincian minggu efektif (RME) A-2 sebesar $88 \%$ dengan kategori sangat siap, B-2 sebesar $75 \%$ dengan kategori siap, C-2 sebesar $75 \%$ dengan kategori siap, dan D-2 sebesar 75\% dengan kategori siap ; persentase perencanaan A-2 sebesar $82 \%$ dengan kategori sangat siap, B-2 sebesar $68 \%$ dengan kategori siap, C-2 sebesar $64 \%$ dengan kategori siap dan D-2 sebesar $64 \%$ dengan kategori siap ; persentase pelaksanaan A-2 sebesar $83 \%$ dengan kategori sangat siap, B-2 sebesar $61 \%$ dengan kategori siap, C-2 sebesar $63 \%$ dengan kategori siap, dan D-2 sebesar 58\% dengan kategori cukup siap; dan persentase evaluasi A-2 sebesar $100 \%$ dengan kategori sangat siap, B-2 sebesar $75 \%$ dengan kategori siap, C-2 sebesar $75 \%$ dengan kategori siap, dan D-2 sebesar 75\% dengan kategori siap. Rata-rata persentase kesiapan guru IPA SMP negeri 2 Stabat sebesar $70 \%$ dengan kategori siap.

Hasil observasi kesiapan guru IPA SMP negeri 5 Stabat menunjukkan bahwa persentase prota dan prosem A-5 sebesar 75\% dengan kategori siap, B-5 sebesar 75\% dengan kategori siap, C-5 sebesar 58\% dengan kategori cukup siap, D-5 sebesar 75\% dengan kategori siap dan E-5 sebesar $75 \%$ dengan kategori siap; persentase rincian minggu efektif (RME) A-5 sebesar 88\% dengan kategori sangat siap, B-5 sebesar $88 \%$ dengan kategori sangat siap, C-5 sebesar 88\% dengan kategori sangat siap, D-5 sebesar $88 \%$ dan E-5 sebesar $88 \%$ dengan kategori sangat siap ; persentase perencanaan A-5 sebesar 82\% dengan kategori sangat siap, B-5 sebesar $82 \%$ dengan kategori sangat siap, C-5 sebesar $71 \%$ dengan kategori siap D-5 sebesar 96\% dan E-5 sebesar $89 \%$ dengan kategori sangat siap ; persentase pelaksanaan A-5 sebesar 72\% dengan kategori siap, B-5 sebesar 78\% dengan kategori siap, C-5 sebesar $78 \%$ dengan kategori siap, D-5 sebesar $78 \%$ dengan kategori siap dan E-5 sebesar $81 \%$ dengan kategori sangat siap; dan persentase evaluasi A-5 sebesar $75 \%$ dengan kategori sangat siap, B-5 sebesar $75 \%$ dengan kategori siap, C-5 sebesar 100\% dengan kategori sangat siap, D5 sebesar $100 \%$ dan E-5 sebesar 100\% dengan kategori sangat siap. Rata-rata persentase kesiapan guru IPA SMP se- kecamatan Stabat sebesar $78 \%$ dengan kategori siap.

\section{SIMPULAN}

Berdasarkan hasil penelitian maka diperoleh simpulan sebagai berikut.
1. Guru IPA SMP Negeri se-Kecamatan Stabat dinyatakan siap dalam menyiapkan pembelajaran kurikulum 2013, hal ini dapat dilihat dari rata-rata persentase sebesar 79 $\%$ dengan kategori siap.

2. Guru IPA SMP Negeri se-Kecamatan Stabat memiliki kategori siap dalam menyiapkan perangkat pembelajaran kurikulum 2013, hal ini dapat dilihat dari data sebagai berikut: (a) Rata-rata persentase kesiapan guru IPA SMP negeri 1 Stabat sebesar $79 \%$ dengan kategori siap; (b) Rata-rata persentase kesiapan guru IPA SMP negeri 2 Stabat sebesar $70 \%$ dengan kategori siap; dan Rata-rata persentase kesiapan guru IPA SMP negeri 5 Stabat sebesar $78 \%$ dengan kategori siap.

\section{SARAN}

1. Guru harus menggunakan perangkat pembelajaran yang dapat menunjang penerapan kurikulum 2013. Salah satu perangkat pembelajaran yang terpenting adalah materi yang berkenaan dengan mendeskripsikan tentang penyebab terjadinya pemanasan global dan dampaknya bagi ekosistem, mengagumi keteraturan dan kompleksitas ciptaan tuhan tentang aspek fisik dan kimiawi kehidupan dalam ekosistem dan peranan manusia dalam lingkungan serta mewujudkannya dalam pengamalan ajaran agama yang dianutnya, dan menerapkan konsep kemagnetan, induksi elektromagnetik dan pemanfaatan medan magnet dalam kehidupan sehari-hari termasuk pergerakan/ navigasi hewan untuk mencari makan dan migrasi. Tanpa perangkat tersebut, siswa akan mengalami kesulitan dalam memahami materi yang diajarkan.

3. Guru harus menyampaikan aspek - aspek yang menjadi fokus penilaian dalam kurikulum 2013 kepada siswa. Dengan demikian, siswa akan berusaha memaksimalkan aspek - aspek yang menjadi fokus penilaian dalam pembelajaran.

4. Terkait proses pembelajaran, guru harus melakukan pendampingan dan pengamatan secara intensif terhadap siswa (dalam kelompok maupun individu) untuk bisa mengetahui kesulitan yang dialami siswa pada tahap tertentu. Selain itu, guru dapat melakukan wawancara tak terstruktur untuk menanyakan kesulitan - kesulitan yang 
dialami siswa guna menemukan solusi pemecahan kesulitan yang tepat.

\section{DAFTAR RUJUKAN}

Febriyaningrum, Retno. (2014). Kemampuan Guru IPA dalam Penerapan Kurikulum di SMP Boyolali Tahun 2013/2014. Surakarta: http://www.http://eprints.ums.ac.id/3 0031/20/NASKAH_PUBLIKASI.pdf.

Miles, Matthew B. and A. Michael Huberman. (2007). Analisis Data Kualitatif. Jakarta: UI Press.

Moleong, Lexy J. (2012). Metodologi Penelitian Kualitatif. Bandung : Rosda.

Nasution. (2003) . Model Penelitian Naturalistik Kualitatif. Bandung: Tarsito.

Purwanto, N. (2009). Prinsip-prinsip dan Teknik Evaluasi Pengajaran. Bandung: Resda.

Sudjana, N. (2005). Media Pengajaran. Bandung: Sinar Baru.

Sugiyono, A. (2012). Metode Penelitian Pendidikan Pendekatan Kuantitatif, Kualitatif dan $R$ \& D. Bandung: Alfabeta.

Syaepudin, U. (2007). Metode Penelitian.Bandung: UPI.

Qomariyah. (2014). Kesiapan Guru dalam Menghadapi Implementasi Kurikulum 2013.Semarang:http://download.Port algaruda.org/article.php?article $=2674$ 31\&val $=6770 \&$ title $=$ KESIAPAN $\% 2$ OGURU\%20DALAM\%20MENGHA DAPI\%20IMPLEMENTASI\%20KU RIKULUM\%202013 